DOE/MC/10637-92/C0002

High-Yield Hydrogen Production by Catalytic Gasification of Coal or Biomass

Author:

Hauserman, William B.

Contractor:

University of North Dakota

Energy and Environmental Research Center

Box 8213, University Station

Grand Forks, North Dakota 58202

Contract Number:

DE-FC21-86MC10637

Conference Title:

Hydrogen '92

Conference Location:

Paris, France

Conference Dates:

June 22-25, 1992 


\section{DISCLAIMER}

This report was prepared as an account of work sponsored by an agency of the United States Government. Neither the United States Government nor any agency thereof, nor any of their employees makes any warranty, express or implied, or assumes any legal liability or responsibility for the accuracy, completeness or usefulness of any information, apparatus, product, or process disclosed, or represents that its use would not infringe privately owned rights. Reference herein to any specific commercial product, process, or service by trade name, trademark, manufacturer, or otherwise, does not necessarily constitute or imply its endorsement, recommendation, or favoring by the L'nited States Government or any agency thereof. The views and opinions of authors expressed herein do not necessarily state or reflect those of the United States Government or any agency thereof.

This report has been reproduced directly from the best available copy.

Available to DOE and DOE contractors from the Office of Scientific and Technical Information, P.O. Box 62, Oak Ridge, TN 37831; prices available from (615)576-8401, FTS 626-8401.

Available to the public from the National Technical Information Service, U.S. Department of Commerce, 5285 Port Royal Rd., Springfield, VA 22161. 


\title{
HIGH-YIELD HYDROGEN PRODUCTION BY CATALYTIC GASIFICATION OF COAL OR BIOMASS
}

\author{
William B. Hauserman \\ Energy and Environmental Research Center \\ University of North Dakota \\ Box 8213, University Station \\ Grand Forks, ND 58202 USA
}

\begin{abstract}
Gasification of coal or wood, catalyzed by soluble metallic cations to maximize reaction rates and hydrogen yields, offers a potential for large-scale, economical hydrogen production with near-commercial technology. With optimum reaction conditions and catalysts, product gas rich in both hydrogen and methane can be used in fuel cells to produce electricity at efficiencies nearly double those of conventional power plant. If plantation silvaculture techniques can produce wood at a raw energy cost competitive with coal, further enhancement of product gas yields may be possible, with zero net contribution of $\mathrm{CO}_{2}$ to the atmosphere.
\end{abstract}

\section{INTRODUCTION}

The rates of reactions in gasification of coal or wood are determined partially by their carbonaceous structure, but mainly by the quantity and chemical form of metallic elements, either inherent in their ash or added as catalysts. Reactivity is defined for the steam-char reaction $\left(\mathrm{C}+\mathrm{H}_{2} \mathrm{O} \rightarrow-\rightarrow \mathrm{H}_{2}+\mathrm{CO}\right)$ as follows:

$$
\mathrm{dC} / \mathrm{d} \mathrm{T}=\mathrm{k} \mathrm{C}^{\mathrm{n}}
$$

where $\mathrm{C}=$ the remaining weight fraction of carbon in the reaction system.

$\mathrm{k}=$ the reactivity rate constant, $\mathrm{hr}^{-1}$.

$\mathrm{n}=$ the order of reaction, approximately $\mathrm{n}=1$ in most cases.

This is the dominant reaction determining overall rates of coal gasification. Addition of salts or minerals high in mobile calcium, potassium, or sodium may increase reactivities by over an order of magnitude. This, in turn, can decrease gasifier residence time and thus the capital investment per throughput. Proper selection of these catalysts, as well as those containing iron, can result in product gases containing over $45 \%$ hydrogen and $10 \%$ methane in fluidized-bed gasifiers. The objective of ongoing programs at the Energy and Environmental Research Center (EERC) is to optimize catalyst selection and identify gasifier design problems by tests ranging from thermogravimetric analysis (TGA) of. 20. to $50-\mathrm{mg}$ samples to pilot plant operations of possibly $50 \mathrm{~kg} / \mathrm{hr}$ (1-3). Reactivity is determined by TGA using 20- to 50-mg samples of coal (4-6) or wood (7). Proper catalyst selection can be a major factor in optimization of reaction rates and product gas compositions for the full range of coal-to-hydrogen applications shown in Figure 1 .

The reactivity of low-rank coals (lignite and subbituminous) is intrinsically higher than that of bituminous coals because their ash levels tend to be high, with more metallic cations organically bound to the coal xather than as grains of stable minerals. In general, sodium and potassium are better catalysts than calciun, and all three are more effective to the extent of their chemical mobility (soluble, volatile, or ionized). The degree of reactivity enhancement by added catalyst is most striking wi.th some bituminous coais and wood, wiere the adidion 
of a high ratio of potassium ions to fixed carbon may increase the steam-char reaction rate by $350 \%$. Selection of catalysts will be primarily a site-specific, and coal-specific, economic decision. Since most catalytic metals leave the gasifier as soluble salts, they can be recycled by ash leaching.

\section{FFECTS OF CATALYSIS ON REAC'TIVITIES}

Coals vary widely in their intrinsic or self-catalyzed reactivity, as shown in TGA data (dC/dt) in Figure 2, which is attributed to their ash content plus the kind and chemical form of metallic elements in it. Table I shows a comparison of analyses of several coals plus wood. The wood is hybrid poplar, which showed the greatest economic potential as an energy crop among species under study in the U.S. While ash content has no consistent correlation with geologic age, the proportion of metallic cations organically bound to the carbonaceous structure increases in younger coals. Wood, though a coal of zero age with all cations except silicon and aluminum in organically bonded form, fails to show a higher: reactivity solely because of its extremely low ash levels. Table II shows TGA data for a variety of coals and wood, with the addition of various catalysts at various temperatures. Catalysis allows economic operation at a lower temperature, making gasification more energy efficient and permitting greater control over product gas composition. In Figure 3, further TGA data shows the effects of adding potassium-bearing catalysts to a subbituminous coal and rood to ircrease their reactivity at a common temperature. While underutilized low-rank coals (lignite and subbituminous) are attractive gasification feedstocks for hydrogen production, the greatest benefit of catalyst addition is with bituminous coals.

\section{INTEGRATION OF CATALYTIC GASIFIERS WITH FUEL CELLS}

With increased reactivity, gasifiers may operate at lower temperatures than would otherwise be feasible. Combined with higher pressures and iron-containing catalysts, this enables high levels of methane and hydrogen. Such gasifiers, integrated with advanced fuel cells, can produce electric power at overall efficiencies probably exceeding $60 \%(6,8,9)$. Thus could electric power could be produced from half the amount of coal required by ccnventional power plants, operating at $32-35 \%$ efficiency, producing half the $\mathrm{CO}_{2}$ per kilowatt. Such a system is shown conceptually in Figures 4 and 5 . In such a system, enhanced reactivity of bituminous coal, achieved by recycled potassium catalyst, could enable operation at around $650^{\circ} \mathrm{C}$, which is an optimum temperature to promote the exothermic methanation reaction, $\mathrm{C}+2 \mathrm{H}_{2} \rightarrow 2 \mathrm{CH}_{4}$, which is further encouraged at higher pressures. The advanced fuel cell oxidizes hydrogen to produce electricity and reduces methane at an electrode surface by the endothermic reaction shown in Figure 5, providing more hydrogen and cooling for the fuel cell, eliminating costly external cooling and heat recovery. Conveniently, the optimum operating temperature for this kind of fuel cell. is also $650^{\circ} \mathrm{C}$, which would eliminate the need for gas cuoling. Thus, with the addition of an electrochemical hydrogen transfer device in the excess hydrogen return line, such a system can approach autothermal operation, reduce the number of heat transfer and energy recovery steps, greatly reduce the oxygen requirement, achieve higher conversion efficiencies, and reduce capital components. In supporting efforts at EERC (10) on catalyst selection for hydrogen-methane coproduction, preliminary results indicate some combination of mobilt potassium and iron compounds may be optimal, with a fluidized bed of limestone.

\section{PILOT-SCALE CATALYTIC GASIFICATION TESTS}

Following TGA tests as an inexpensive screening step, further evaluation of catalysts and reactor conditions is done in EERC's small, continuous process unit shown schematically in Figure 6, originally used for pyrolysis research. Heat is supplied externally. To match this performance in a larger-scale gasifier requires the introduction of some oxygen and burning additional coal to supply heat, resulting in some product dilution by $\mathrm{CO}_{2}$. If the ideal autothermal operation 
described above can be achieved oxygen will not be needed. Some preliminary results comparing the effects of temperature, pressure, and potassium impregnation on the gasification of Wyodak coal in a fluidized limestone bed are summarized in Table III, along with some corresponding data for wood, which was done first, under poorly controlled reactor conditions. These are the first two data sets generated by the experimental device in a newly modified configuration, however, and not part of orderly experimental matrix. Evaluation of data to determine yields is still in progress. The data of Table III is of present interest to show the high percentages of hydrogen and methane possible and their sensitivity to the four experimental parameters shown. The runs using coal proceeded smoothly, with steady-state conditions and no problems of feed plugging or bed agglomeration, as experienced in the earlier runs with wood chips. This confirms earlier observations, using larger gasifiers with coal, that a homogenous catalyst, impregnated onto the feed, avoids mechanical problems caused by heterogenous catalysts.

\section{EXTENSION OF COAL GASIFICATION TECHNOLOGY TO BIOMASS}

Coal gasification is well established commercially, with great reserves of nextgeneration technology available for acselerated development as favorable economic conditions arise or as national policies promote energy independence or greater. conversion efficiency. Extension of this technology to wood depends only upon minor changes in component design and raising enough wood economically. Economic studies indicate that hybrid poplars can be grown and harvested by the year 2000 at a delivered energy cost comparable to the present upper limits of coal-mining costs [11]. The integrated gasifier-fuel cell concept [8,9] of Figure 4 is expected to acnieve roughly twice the conversion efficiency of conventional coalfired power plants, thus halving the $\mathrm{CO}_{2}$ emission per $\mathrm{kW}$. Substituting wood for coal would eliminate $\mathrm{CO}_{2}$ completely. The key is finding enough suitable land to grow the trees. As a good example, the state of Minnesota, U.S.A., has significant areas of marginally utilized land that have demonstrated high growth rates of Populus species. The current population of about $3,388,600$ has an annual power consumption of $13,560 \mathrm{kWhr}$ per capita [1.2]. Assuming three observed levels of productivity [11], in annualized dry metric tons per hectare, conversion to electric power at $60 \%$ efficiency would require the plantation areas shown in Figure 7.

\section{Acknowledgements}

In addition to all of the EERC staff who have contributed efforts in various projects summarized in this paper, the author wishes to thank the following funding agencies for their support, encouragement, and patience.

- U.S. Department of Energy, Morgantown Energy Technology Center, Morgantown, West Virginia

- Energy Research Corporation, Danbury, Connecticut

- U.S. Department of Agriculture, Cooperative State Research Services, Washington, DC

- The University of Minnesota at Crookston

\section{REFERENCES}

1. Hauserman, W.B. et al. "Production of Hydrogen from Low-Rank Coals," Semiannual Report (USDOE Contract No. DE-FC21-86MC10637), January 1.992.

2. Hauserman, W.B. et al. "Production of Hydrogen from Low-Rank Coals," Annual. Report (Contract No. DE-FC21-86MC10637), August 1990. 
3. Sears, R.E. et al. "Production of Hydrogen from Low-Rank Coals," (Contract No. DE-FC21-86MC10637), Topical Repori, August 1.989.

4. Timpe, R.C. et a1. "Hydrogen from Low-Rank Coals: Char Properties and Reactivity of Gasification Feedstocks," Ind. Eng. Chem. Res, 1981, 30, 2.

5. Timpe, R.C. et a1. "Gatalytic Effect on the Gasification of a Bituminous Argonne Premium Coal Sample Using Wood. Ash or Taconite as an Additive," Fuel Chemistry Division, American Chemical Society, Fa11 1991.

6. Timpe, R.C. et al. "Characteristics of Gasification Coal Char," 7 th Annual International Pittsburgh Coal Conference, 1990.

7. Hauserman, W.B.; Timpe, R.C. "Transfer of Emerging Coal Conversion processes to Woody Biomass Energy Crops," Southern Biomass Conference, Baton Rouge, LA, January 1991 .

8. Steinfeld, G. (Energy Research Corporation); Hauserman, W.B. "Design of Gasifiers to Optimize Fuel Cells," U.S. DOE Gasification Contractors' Review Meeting, Morgantown, WV, October 16-18, 1991.

9. Farooque, M. et a1. (Energy Research Corp, and F1uor-Danie1, Inc.) "Assessinent of Coal Gasification/Carbonate Fuel Cell Power Plants: Topical Report," USDOE Contract No. DE-AVC21-7MC23274, June 1990.

10. Sondreal, E.A. et al. "Recommendations for Disposable Gasification Catalysts to Optimize Integrated Gasifier/Fuel Cell Systems, "Report to Energy Research Corp. , January 1991.

11. Raney, J.M. et a1. "Short Rotation Woody Crops Program Annual Progress Report for 1987," ORNL-6440, August 1988.

12. Minnesota-Wisconsin Power Supply Group, "199i Advanced Forecast to NEQB and DPS , " 1991. 


\begin{tabular}{|c|c|c|c|c|}
\hline & Coal $A^{1}$ & $\underline{\text { Coal B }}$ B $^{2}$ & Coal $1 \mathrm{C}^{3}$ & Wood 4 \\
\hline $\begin{array}{l}\text { Geologic Age } \\
1,000,000 \text { Years }\end{array}$ & $200-400$ & $70-100$ & $50-70$ & 0 \\
\hline Proximate, Wt $\%$ dry basis & & & & \\
\hline $\begin{array}{l}\text { Volatiles }\left(900^{\circ} \mathrm{C}\right) \\
\text { Fixed Carbon } \\
\text { Ash }\end{array}$ & $\begin{array}{l}41 \\
46 \\
12\end{array}$ & $\begin{array}{r}45 \\
46 \\
9\end{array}$ & $\begin{array}{r}47 \\
46 \\
7\end{array}$ & $\begin{array}{c}83 \\
13 \\
4-\end{array}$ \\
\hline $\begin{array}{l}\text { Ash, } \mathrm{XRFA}^{5}, \% \text { as oxides } \\
\mathrm{SiO}_{2} \\
\mathrm{Al}_{2} \mathrm{O}_{3} \\
\mathrm{Fe}_{2} \mathrm{O}_{3} \\
\mathrm{CaO} \\
\mathrm{MgO} \\
\mathrm{K}_{2} \mathrm{O} \\
\mathrm{Na}_{2} \mathrm{O} \\
\mathrm{SO}_{3} \\
\text { Other (P, Tl, Etc.) }\end{array}$ & $\begin{array}{r}44 \\
18 \\
18 \\
8 \\
1 \\
3 \\
0 \\
7 \\
1 \\
\end{array}$ & $\begin{array}{r}26 \\
13 \\
7 \\
24 \\
9 \\
1 \\
3 \\
15 \\
2 \\
\end{array}$ & $\begin{array}{r}38 \\
14 \\
8 \\
14 \\
5 \\
1 \\
3 \\
15 \\
2 \\
\end{array}$ & $\begin{array}{r}5.2 \\
1.7 \\
3.8 \\
44.3 \\
15.3 \\
14.5 \\
1.6 \\
6.0 \\
7.6 \\
\end{array}$ \\
\hline
\end{tabular}

1 Typical bituminous, Illinois or Indiana

2 Typical subbituminous, Wyoming.

3 Typical lignite, North Dakota.

4 Specific Hybrid Poplar, Experimental Plantation, NE Minnesota.

5 X-Ray Fluorescence, for elemental analysis.

TABLE II: REACTIVITY DATA FOR VARIOUS COALS AND WOOD (Reactivity, $\mathrm{k}^{-1}$, as determined by TGA)

\begin{tabular}{|c|c|c|c|c|}
\hline Temperature, ${ }^{\circ} \mathrm{C}$ & $\underline{650}$ & $\underline{700}$ & $\underline{750}$ & 800 \\
\hline $\begin{array}{l}\text { Bituminous Coal }{ }^{1} \\
\quad \text { Raw } \\
+20 \% \text { Limestone } \\
+10 \% \mathrm{~K}_{2} \mathrm{CO}_{3} \\
+10 \% \text { Limestone }+10 \% \mathrm{~K}_{2} \mathrm{CO}_{3} \\
+19 \% \text { Hot Wood Ash Leachate }\end{array}$ & $\begin{array}{l}\cdots \\
\cdots \\
\cdots \\
\cdots\end{array}$ & $\begin{array}{c}0.07 \\
\cdots \\
\cdots \\
\cdots \\
0.61\end{array}$ & $\begin{array}{l}0.14 \\
0.59 \\
4.36 \\
5.38 \\
3.01\end{array}$ & $\begin{array}{l}0.33 \\
1.45 \\
\cdots \\
\cdots \\
5.1 .5\end{array}$ \\
\hline $\begin{array}{l}\text { Subbituminous Coal }{ }^{2} \\
\quad \text { Raw } \\
\quad+10 \% \quad \mathrm{~K}_{2} \mathrm{CO}_{3}\end{array}$ & $\begin{array}{l}0.37 \\
1.25\end{array}$ & $\begin{array}{l}1.16 \\
4.3\end{array}$ & $\begin{array}{l}1.31 \\
8.24\end{array}$ & $\begin{array}{r}3.06 \\
13.48\end{array}$ \\
\hline $\begin{array}{l}\text { Lignite }^{3} \\
\quad \text { Raw } \\
\quad+20 \% \text { Limestone } \\
+10 \% \mathrm{~K}_{2} \mathrm{CO}_{3}\end{array}$ & $\begin{array}{l}0.30 \\
0.48 \\
1.35\end{array}$ & $\begin{array}{l}1.3: \\
0.81 \\
4.06\end{array}$ & $\begin{array}{l}2.10 \\
6.49 \\
8.17\end{array}$ & $\begin{array}{r}3.56 \\
15.50 \\
34.90\end{array}$ \\
\hline $\begin{array}{l}\text { Weod }^{4} \\
\quad \text { Raw } \\
\quad+10 \% \text { Wood Ash }\end{array}$ & - & $\begin{array}{l}0.13 \\
4.18 \\
\end{array}$ & $\begin{array}{l}0.33 \\
9.84 \\
\end{array}$ & $\begin{array}{r}3.10 \\
18.24 \\
\end{array}$ \\
\hline
\end{tabular}

$1,2,3,4$ - see TABLE I 
TABLE III: CONTINUOUS PROCESS UNIT GAS COMPOSITION OF WYODAK COAL AND WOOD IN FLUIDIZED BED OF LIMESTONE

Wyodak Coal

Temperature, ${ }^{\circ} \mathrm{C}$ :

$\begin{array}{llllll}700 & 700 & 700 & 700 & 600 & 700 \\ 2.4 & 6.1 & 2.4 & 2.4 & 2.4 & 2.4\end{array}$

Pressure, Atm.:

None None None $4.4 \% \mathrm{KOH}$ Impregnated $\rightarrow$

Catalyst:

Steam/Carbon, mol:

2

2

1

2

2

1

Product Gas, dry, inert-free

$$
\begin{aligned}
& \% \mathrm{H}_{2} \\
& \% \mathrm{CO} \\
& \% \mathrm{CO}_{2} \\
& \% \mathrm{CH}_{4} \\
& \% \mathrm{C}_{2} \& \mathrm{C}_{2}+
\end{aligned}
$$

Hybrid Poplar Wood

Temperature, ${ }^{\circ} \mathrm{C}$ :

Pressure, Atm.:

Catalyst:

Steain/Carbon, mol:

Product, Dry and Inert-Free

$$
\begin{aligned}
& \% \mathrm{H}_{2} \\
& \% \mathrm{CO} \\
& \% \mathrm{CO}_{2} \\
& \% \mathrm{CH}_{4} \\
& \% \mathrm{C}_{2} \& \mathrm{C}_{2+}
\end{aligned}
$$

56.8

62.6

58.6

63.1

60.0

8.7

2.1

25.4

28.7

25.0

2.7

0.3

0.0

9.0

0.3

56.2

16.6

7.7

0.3

700

650

650

$\begin{array}{cccccc}600 & 650 & 700 & 700 & 650 & 650 \\ 2.4 & 2.4 & 2.4 & 4.4 & 4.4 & 7.8\end{array}$

…... D D
3.0
1.1
1.1
1.1
1.0
1.0

\begin{tabular}{rrrrrc}
48.0 & 52.0 & 50.0 & 51.8 & 51.3 & 61.5 \\
8.0 & 6.0 & 12.0 & 15.6 & 7.7 & 38.5 \\
35.0 & 34.0 & 30.0 & 26.5 & 28.0 & - \\
7.0 & 6.0 & 6.0 & 5.2 & 10.0 & - \\
2.0 & 3.0 & 2.0 & 0.0 & 3.0 & - \\
\hline
\end{tabular}

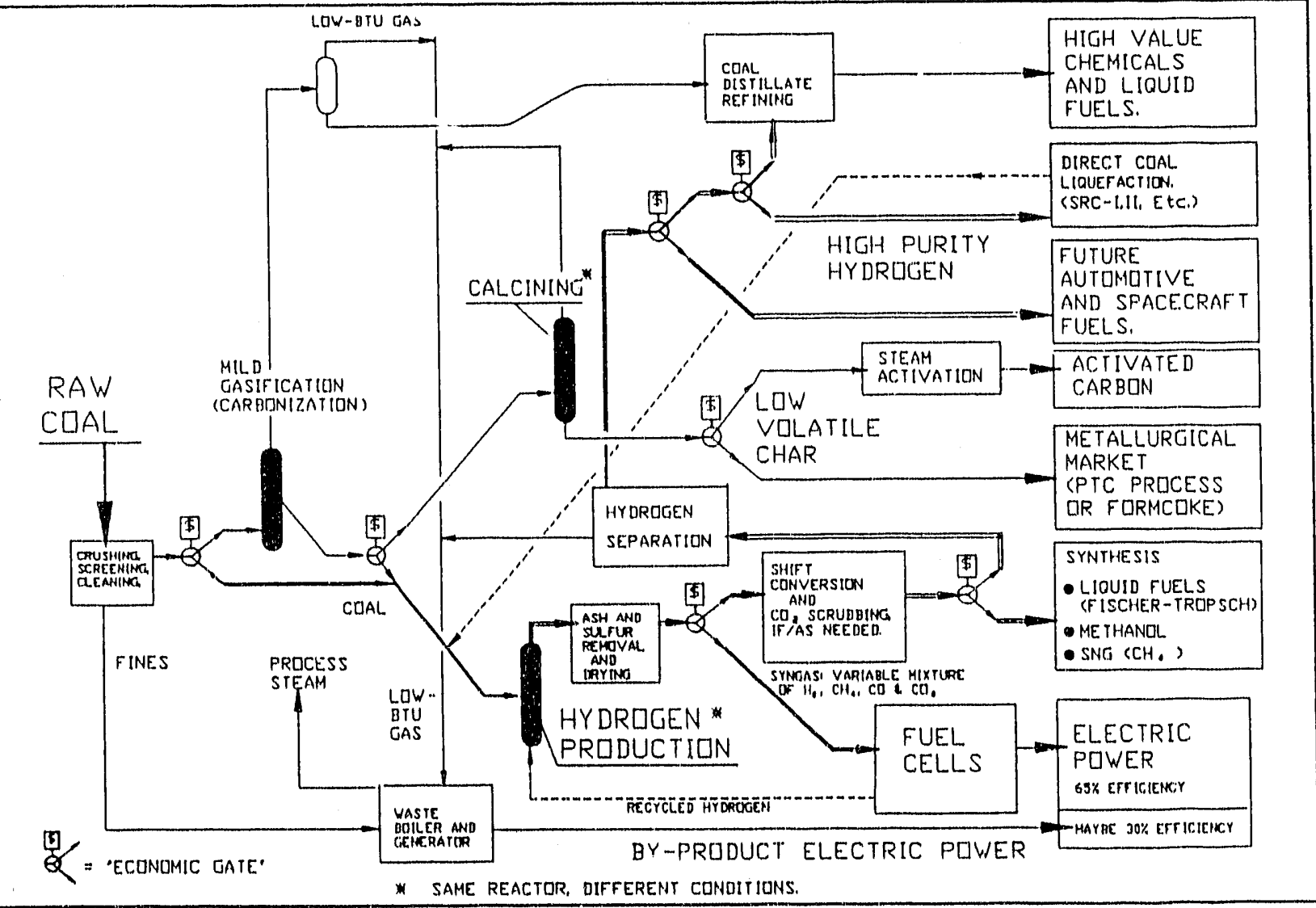

Fig. 1 - Multiple Markets for Hydrogen from Coal 


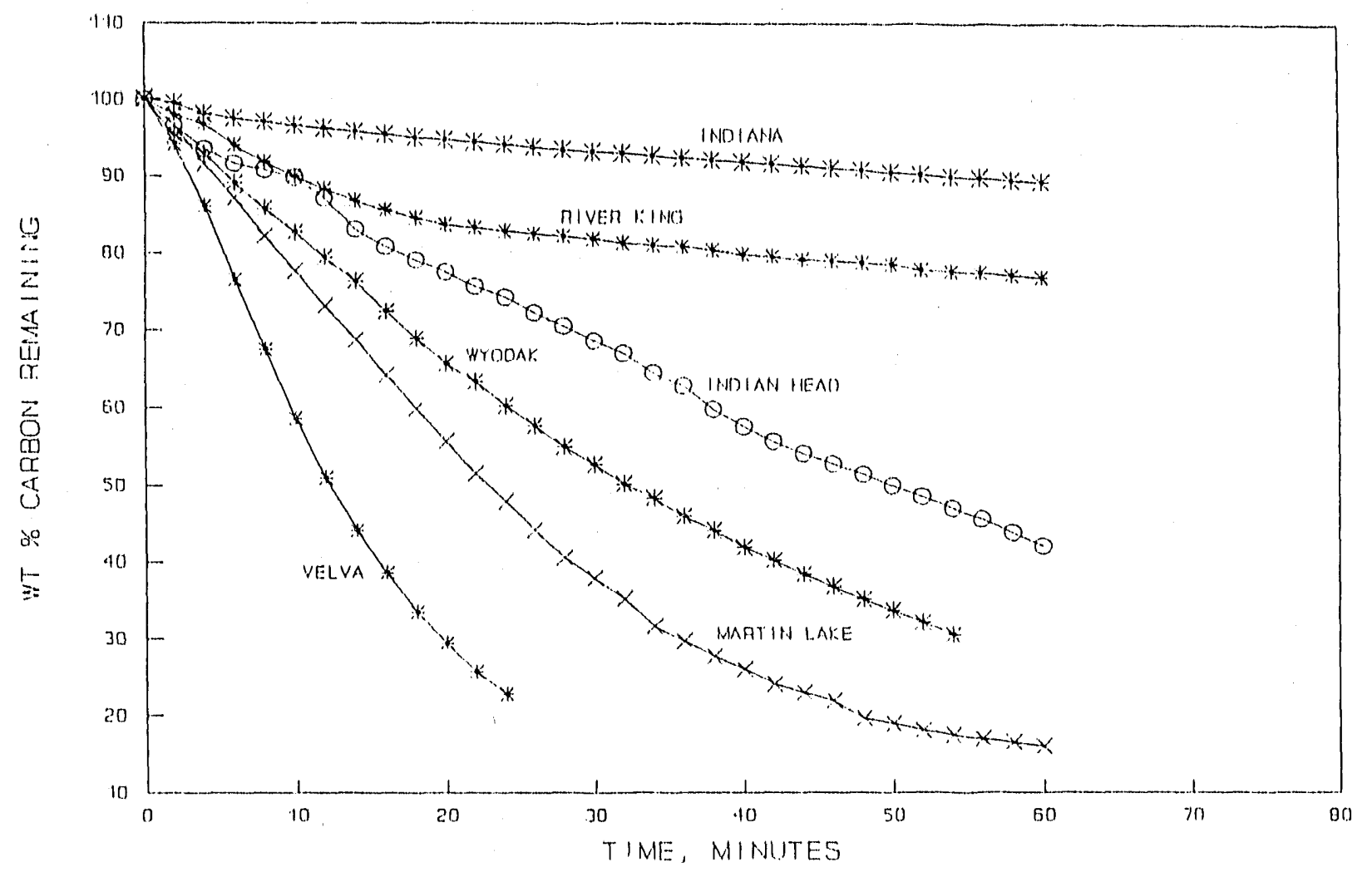

Fig, 2 - Intrinsic Reactivities of Various Coals and Wood

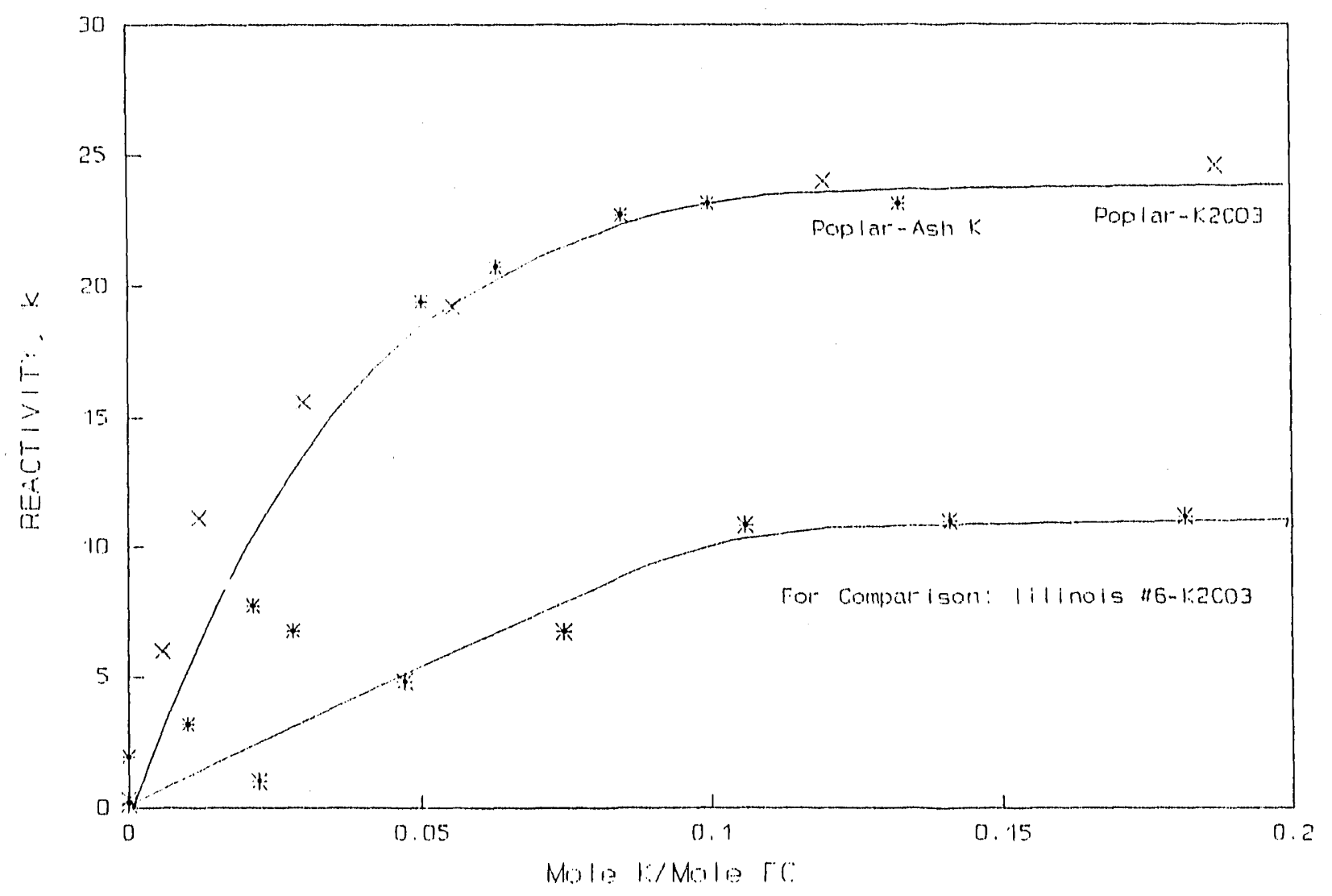

Fig. 3 - Effects of Potassium Catalyst Addition on Reactivities of Coals and Wood 


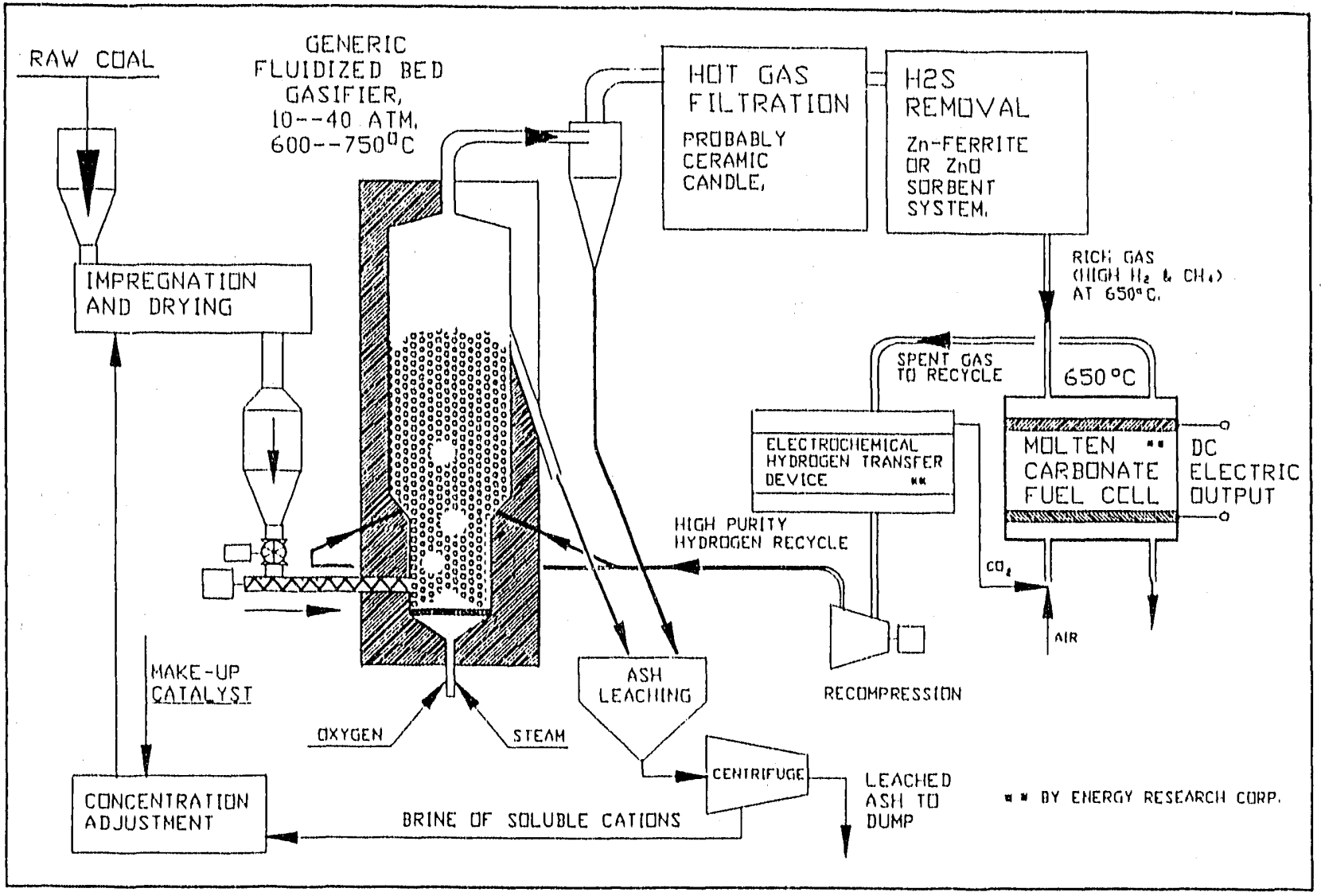

Fig. 4 - Catalytic Fluid-Bed Gasifier Integrated with Molten Carbonate Fuel Ce11

LEAN RECYCLE TO $\mathrm{H}_{2}$ RECQVERY

RICH GAS FRIM GASIFIER

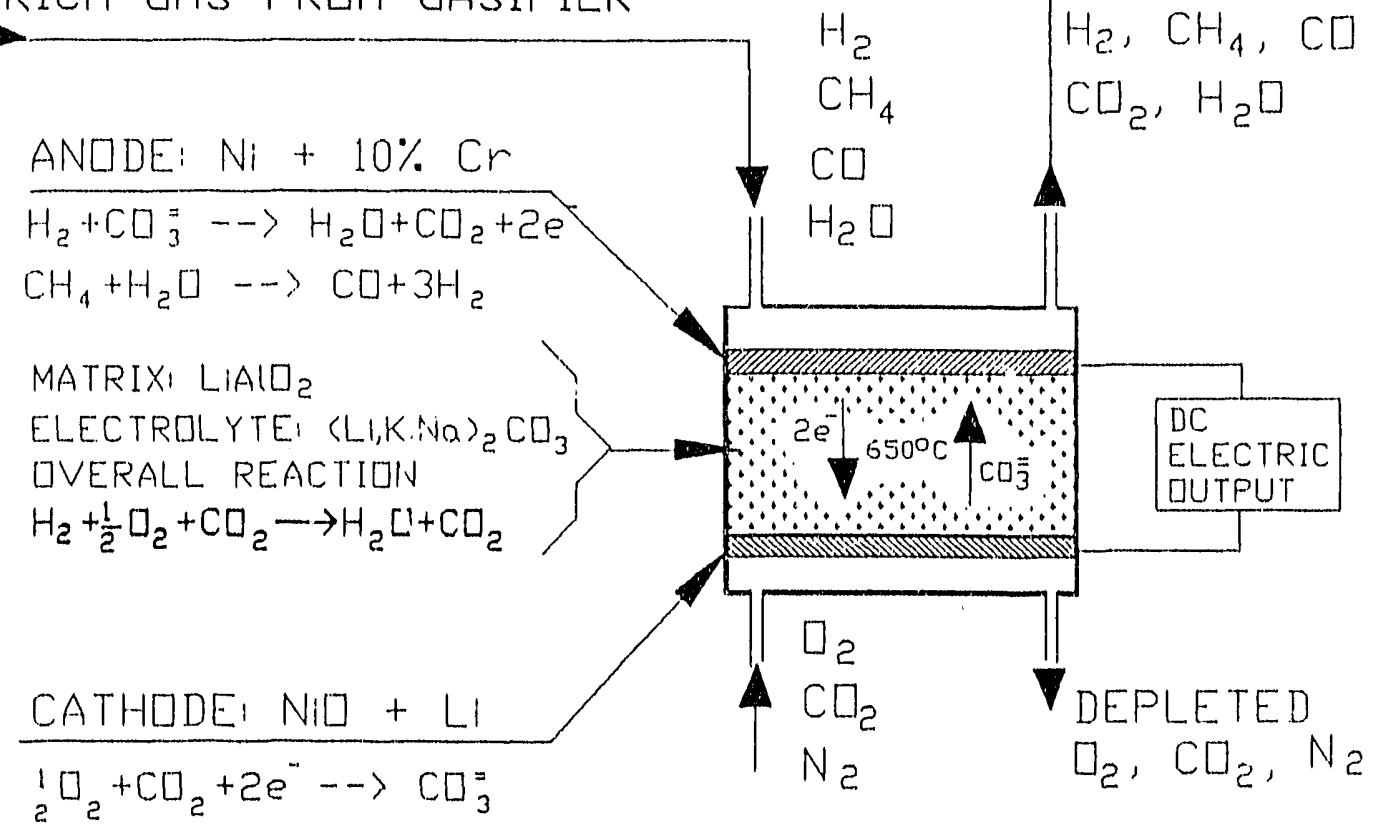

MILTEN CARBDNATE FUEL CELL (ENERGY RESEARCH CORP, )

Fig. 5 - Advanced Molten Carbonate Fuel Ce1.1 


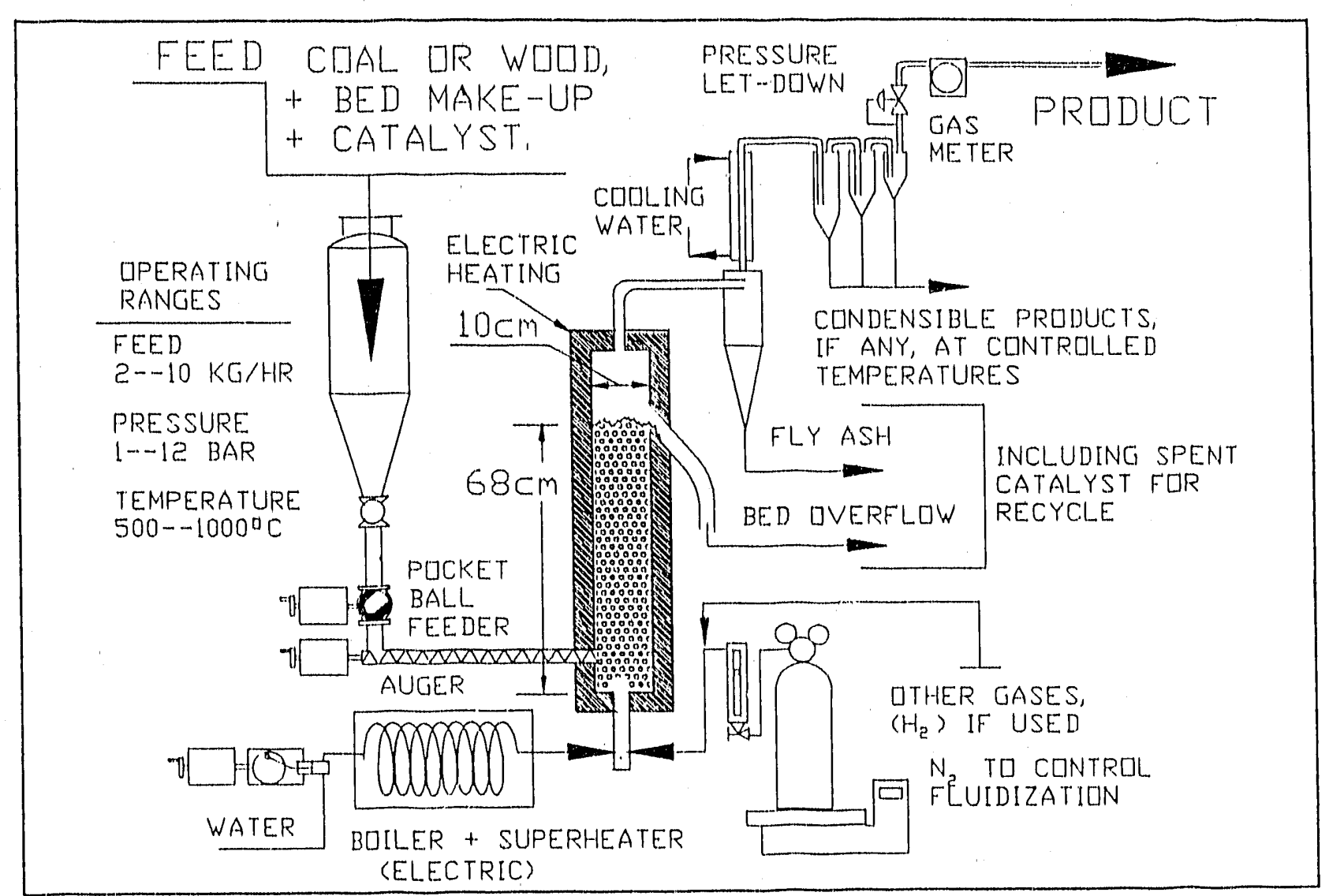

Fig. 6 - EERC's Sma11, Pilot-Scale Continuous Process Unit

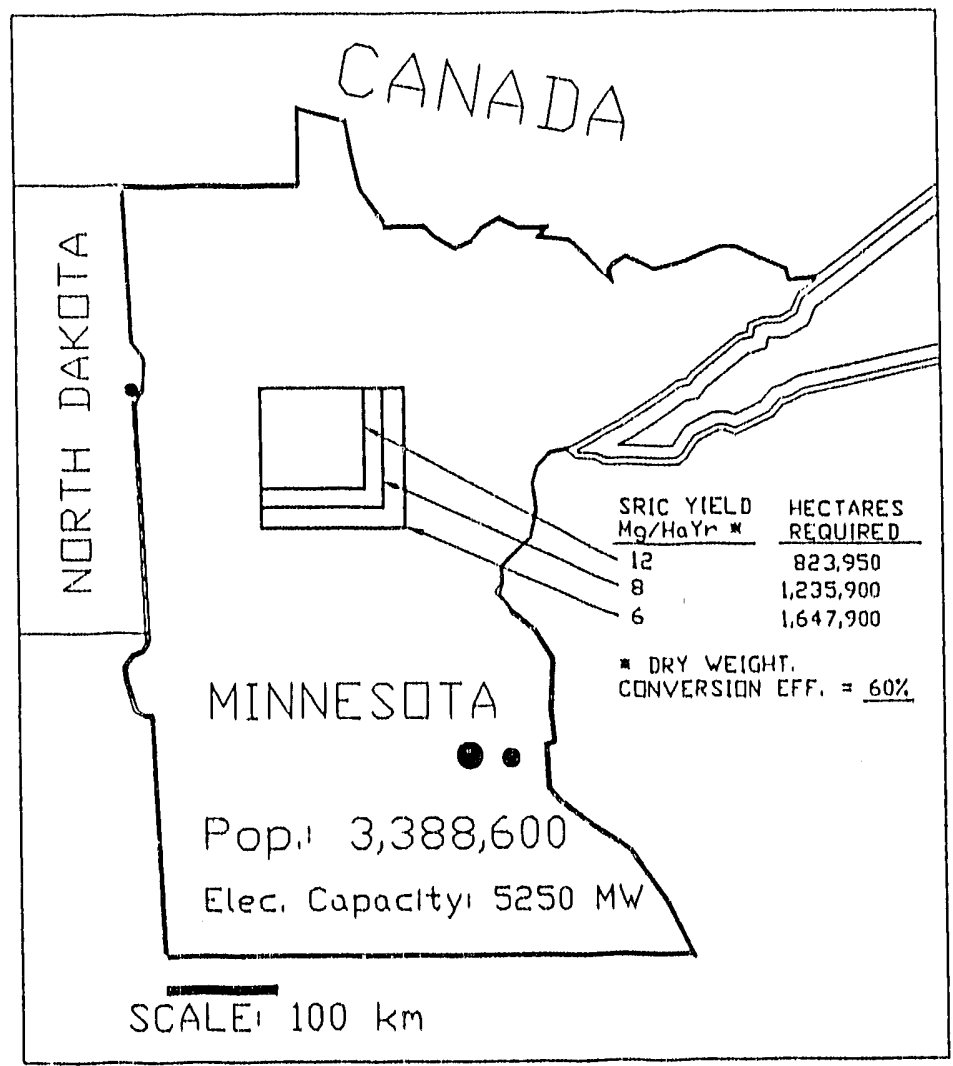

Fig. 7 - Biomass Potential for Electric Power Supply in Minnesota 

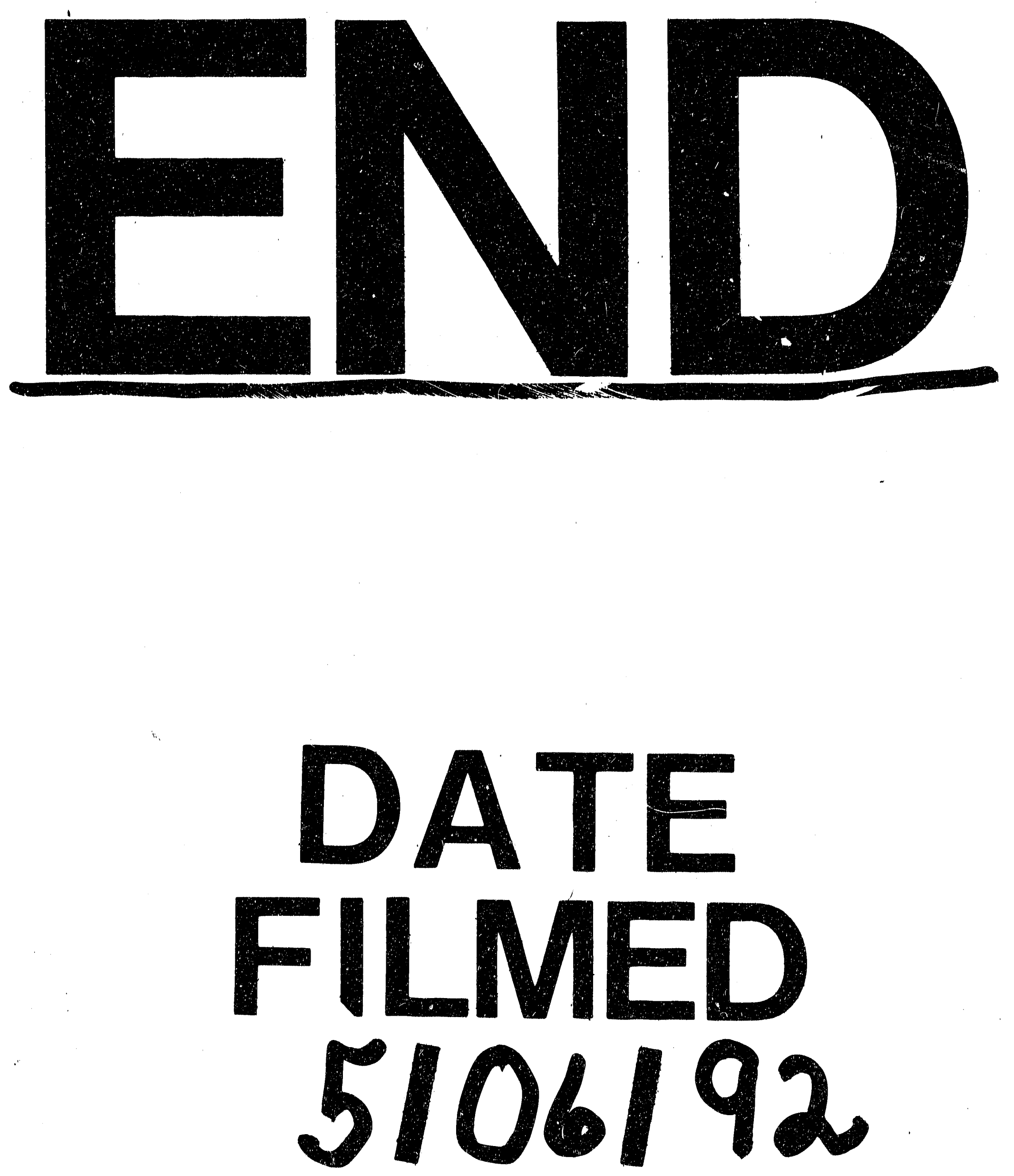